\title{
Imaginative Game of Treasure Hunt to Develop Early Childhood's Visual-Spatial Intelligence
}

\author{
Sherin Maudri Asy'ari ${ }^{1, *}$, Yeni Rachmawati ${ }^{2}$, Rita Mariyana ${ }^{3}$ \\ ${ }^{1,2,3}$ Early Childhood Education Study Program, Faculty of Educational Science, Universitas Pendidikan Indonesia \\ *Corresponding author.Email: maudriasyarisherin@student.upi.edu
}

\begin{abstract}
This study aims to solve the issue on the development of visual-spatial intelligence in children and find out whether the implementation of imaginative games of treasure hunt can develop visual-spatial intelligence in early childhood. The research method used in the classroom action research method (CAR) with the research location in Kemala Bhayangkari 41 Kindergarten with 16 participants consisting of ten girls and six boys. The results obtained are the implementation of imaginative games of treasure hunt can improve the development of visual-spatial intelligence in early childhood. This can be seen from the data on the increase in each cycle after learning using imaginative games treasure hunt. Based on the results of this study, it can be recommended that imaginative play of treasure hunt can be used as an effective learning method to develop early childhood visual-spatial intelligence.
\end{abstract}

Keywords: Imaginative game of treasure hunt, visual-spatial intelligence.

\section{INTRODUCTION}

One of the important intelligence of children is visual-spatial intelligence [1]. Visual-spatial intelligence is the ability to understand, process, and think in visual form and visualize it in two or three dimensions. In other words, visual-spatial intelligence is the ability to visualize the images in his mind into a real form [2]. Visual-spatial intelligence has a role in a child's life as a basis for him to adjust to his environment. Students with visual-spatial intelligence will tend to create an image in their mind or the ability to create three-dimensional forms as found in adults who become sculptors or architects [3].

Visual-spatial intelligence is marked by the child's sensitivity in perceiving the visual-spatial world, namely the ability to capture colors and being able to combine colors when coloring and decorating, their enjoyment of scribbling, drawing, fantasizing, making simple designs, children's ability to understand directions and shapes and the child's ability to create a form, such as a house, car or another form that suggests a simple form transformation element [2]. Children's visual-spatial intelligence will develop when trained and stimulated through the experiences they get from the environment, parents, and educators.

Lack of attention from teachers or parents to children's visual-spatial intelligence, lack of stimulus, and lack of play tools in schools will result in limited visual-spatial intelligence for children. When the visualspatial intelligence is underdeveloped, the child will find it difficult to distinguish the location of a place, and it is difficult to determine the direction or lack of sufficiently good imagination [4]. Children with low visual-spatial intelligence have several problems, including not being able to present correctly in determining direction, position, sorting objects from the smallest to the largest, and not estimating the distance and existence of themselves in an object. Visual-spatial intelligence has an important role in the child's life both in the present and in the future [4]. For example, when a person cannot tell a place's location, a person will easily get lost, and it will be difficult to know his own position. A person will also have difficulty socializing or interacting with peers when he cannot convey a meaning in which direction he wants to show.

Based on previous research that discusses visualspatial intelligence, it can be seen that there are still many children who have less developed visual-spatial intelligence. This can be seen from the lack of children's ability to express the ideas they have in mind using the materials or tools provided. When doing collage activities, children are not brave enough to arrange existing materials according to their wishes and creativity [2]. The same thing was found in Kemala Bhayangkari 41 Kindergarten. Based on the results of observations, as many as 14 out of 16 children in group B aged 5-6 years showed an underdeveloped intelligence. The 
underdevelopment of the child's visual-spatial intelligence is indicated by the condition of the child who shows less interest in recognizing an object or shape, his sensitivity to color, is not able and still feels confused in remembering the path he took from home to school, feeling confused and having difficulty learning with tools visual aids, have not been able to compile and build threedimensional games, and are characterized by the limited ability of children's imagination during play and learning activities. The inability of children to understand perceptions of images, colors, shapes and directions related to visual-spatial intelligence is caused by several factors, including the process of teaching and learning activities that are still conventional, the lack of provision and use of supporting learning media, the lack of facilities owned by kindergartens, and lacking in maximizing the use of learning themes to develop children's visual-spatial intelligence.

One of the methods used by researchers in developing and providing a stimulus for the development of children's visual-spatial intelligence is by providing imaginative games of the treasure hunt. The type of game mostly played by children, especially in the early stages of development, is fantasy or imagination. Imaginative play has benefits for children, such as helping children develop thinking and language skills, helping children understand other people, helping children develop their creativity, and recognizing themselves. Through these play activities, children can develop their creativity, namely carrying out activities that contain flexibility, utilizing imagination or self-expression, problem-solving activities, and finding new ways [5].

The imaginative game of treasure hunt was developed to train children's visual-spatial intelligence skills by combining the game of maze (looking for traces) and composing a puzzle, where the child has to go through several tracks and pick up puzzle pieces containing pieces of pictures on each provided post and must be rearranged as a clue to find treasure.

This study generally aims to determine the implementation of imaginative play of treasure hunt in developing visual-spatial intelligence in early childhood in group B children in Kemala Bhayangkari 41 Kindergarten Bandung.

\section{METHOD}

This study uses the Classroom Action Research (CAR) method, a study that involves researchers directly to research subjects to observe the development of visualspatial intelligence in early childhood [6]. Classroom Action Research is a form of reflective study, which action actors carry out to increase the rational ability of their actions in carrying out tasks and deepen understanding of conditions in learning practices [7]. This classroom action research is a type of partnership action or collaborative research carried out in the form of collaboration between the teacher as the implementer of the action and the researcher as the data collector.

The research procedure carried out in this study was in the form of a cycle. The cycle is carried out twice. Each cycle consists of two actions through four steps of research procedures, which include planning, implementing, observing, and reflecting.

\section{- Planning}

The activity begins with an introduction that identifies problems related to the child's ability in visualspatial intelligence. At this planning stage, the researcher collaborates with the teacher to formulate actions that will be taken by making a lesson plan containing objectives, materials, methods, media, and learning evaluation. Prepare scenarios to apply treasure hunt games with the tools and media used and their class settings. Making research tools and instruments in the form of instrument guidance and observation formats to observe teacher performance and children's activities as an effort to improve visual-spatial intelligence.

\section{- Implementing}

The researcher carried out the research with the group B teacher's help at Kemala Bhayangkari 41 Kindergarten. The group B teacher acted as a teacher while the researcher acted as an observer. The teacher becomes a research partner, first understanding the learning through the imaginative game of treasure hunt to run smoothly according to plan. The purpose of this division of tasks is that researchers can focus more on observing the implementation of imaginative games of treasure hunt.

\section{- Observation}

Observation activities are carried out together with the implementation of actions by planning how and what tools to collect data in these observations. The tool used in this activity was an observation format. The focus of research is to improve classroom learning. The purpose of the observation in this step is to determine the extent to which treasure games can develop children's visualspatial intelligence.

\section{- Reflection}

Reflection is an activity of analysis and interpretation of all information obtained from observations. Reflection is an important activity to understand and give meaning to the processes and results of changes resulting from the action of the treasure hunt. The results of observations describe all learning actions so that through reflection, it can be seen whether or not the implementation of the action is suitable for the learning plan. The deficiencies that occur in the implementation of the treasure hunt game can be fixed in the next cycle, while the advantages are maintained. 
All data obtained from observations are used as the basis for evaluating so that if learning is not optimal, steps to improve learning through the imaginative game of treasure hunt can be arranged in the second cycle.

\section{FINDINGS}

\section{The Increased of the Children's Visual-Spatial Intelligence Development after Treasure Hunt Game}

Based on the observations that have been carried out, there is an increase in children's visual-spatial intelligence from the first cycle to the second cycle. There were still $7.40 \%$ of children who had not developed their visual-spatial intelligence in the first cycle. Whereas in the second cycle, none of the children whose development of visual-spatial intelligence had not yet developed. This is much higher compared to the results of the pre-cycle, which is $48 \%$ of children who are still undeveloped.

The development of children's visual-spatial intelligence that began to develop in pre-cycle activities was $52 \%$. Then in the first cycle, there was an increase of $63.30 \%$ children, and in the second cycle, it decreased to $0 \%$. This happens because most children experience development, namely to develop according to expectations.

Children's visual-spatial intelligence development that develops according to expectations in the pre-cycle is none then in the first cycle, and it increases to $29.30 \%$. Furthermore, in the second cycle, it became $17.50 \%$. This happens because the development of most children is increased, namely being very well developed.

Children's visual-spatial intelligence developed very well in the pre-cycle and did not exist or was $0 \%$. Furthermore, in the first cycle, $0 \%$ or no children showed very good development because most of the children developed according to expectations (relevance with the average on the scale). Then in the second cycle, the increase in child development increased to $82.50 \%$, which is very well developed (relevance with an upper level on the scale). This increases drastically because the child can participate in the treasure hunt game very well.

The results of research on pre-cycle, first cycle, and second cycle activities are illustrated in the following diagram:

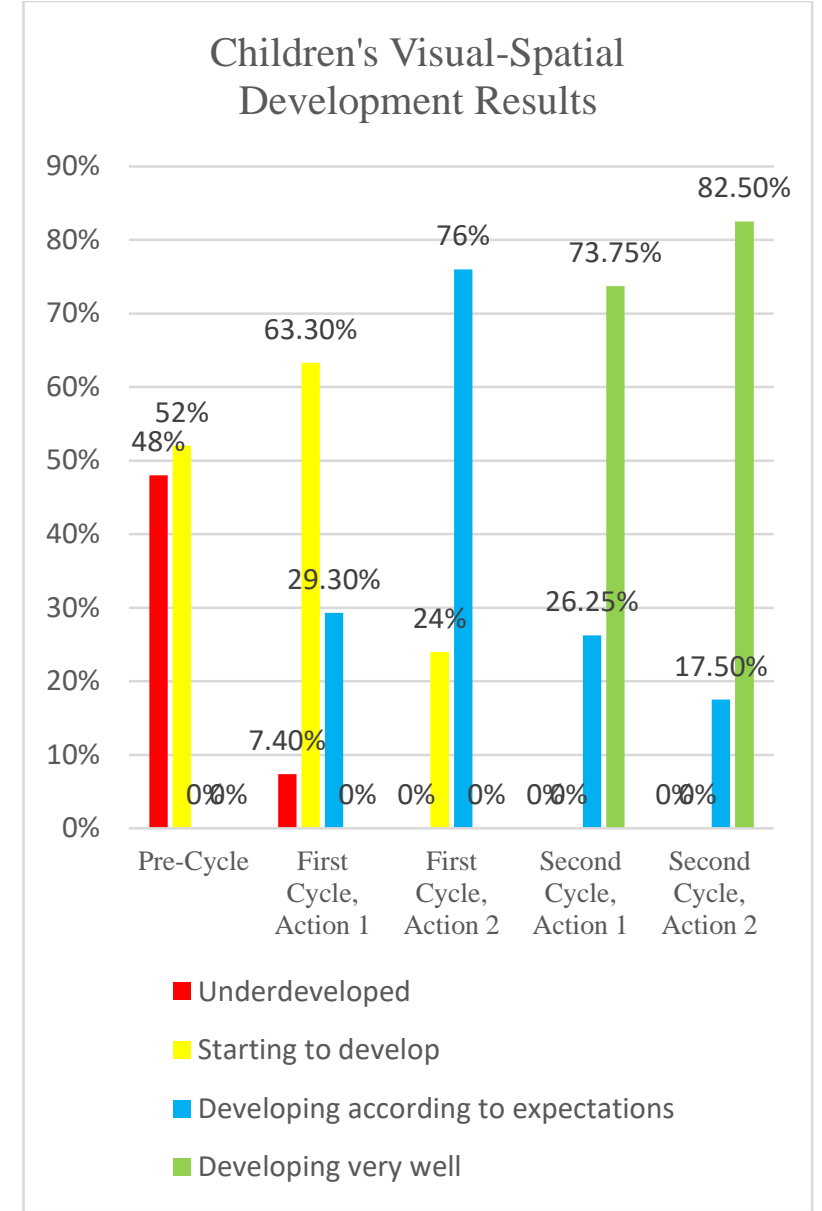

Figure 1 Graph of Children's Visual-Spatial Development Results

Based on the results of research that has been carried out in Group B Kemala Bhayangkari 41 Kindergarten, through the implementation of imaginative games of treassure hunt carried out for two cycles with two actions each, resulting in a good uplift in the development of children's visual-spatial intelligence.

A significant increase was seen in the second cycle, namely in four indicators, including coordinating eyefoot movements when passing obstacles, identifying objects, mentioning the location of an object based on its position with other objects, and knowing the relationship between the position of an object and another object. The four indicators show that there are no children whose developmental stages have not yet developed and are starting to develop. The study results also showed that as many as 16 children experienced significant development; namely, they showed very good developmental stages, including the children were able to understand the teacher's explanation about playing activities independently and were able to explain playing activities to their friends. This increase can be seen from the development of children's visual-spatial intelligence that develops according to expectations, namely $17.50 \%$ and very well developed at $82.50 \%$. 
The development of children's visual-spatial intelligence has increased in each cycle. This happens because the teacher and researchers always carry out evaluations and improvements regarding imaginative play activities of treasure hunt carried out in each cycle. Improvements made in the first cycle are that the teacher uses methods to motivate children to participate in the game of treasure hunt well, for example, by explaining the rules of play more interestingly and simply, providing more interesting instructions, and various kinds of obstacles that are more challenging and fun to use to develop children's visual-spatial intelligence. With evaluation and improvement, children's visual-spatial intelligence has increased in the second cycle. Children can follow instructions given during play activities. During play activities, the children seemed active and responded to various questions raised by the teacher, and did not hesitate to answer questions. Furthermore, when the game of treasure hunt is carried out, the child can understand the rules of playing the game of treasure hunt and can follow the instructions provided, and feel happy when passing through various kinds of obstacles that can stimulate his visual-spatial intelligence.

The ability of children who experience an increase in visual-spatial intelligence is marked by the condition of the child who prefers to show interest in recognizing an object or shape and sensitivity to color, can remember the path he took from home to school, likes to learn with visual aids, likes to compose and build a threedimensional game, and is characterized by increased children's imagination skills during play and learning activities. This is in line with previous research that the imaginative play of treasure hunt can provide several benefits, including training concentration, accuracy, and patience, strengthening memory, introducing children to the concept of relationships, and by choosing pictures can train children to think mathematically (using the left brain), as well as training to solve problems [5]. Through the implementation of imaginative games of treasure hunt, children will also have regular feelings, accuracy, tenacity, logical thinking and increase their imagination in looking and finding treasures to improve brain function.

So that the final results show that the game of treasure hunt can be used as a learning method to develop visualspatial intelligence of group B children in Kemala Bhayangkari 41 Kindergarten because it gives a positive impact on learning activities, especially in developing children's visual-spatial intelligence.

\section{CONCLUSION}

Children's abilities in visual-spatial intelligence are still underdeveloped. The inability of children to understand perceptions of images, colors, shapes, and directions related to visual-spatial intelligence is caused by several factors, including the process of teaching and learning activities that are still conventional in nature, the lack of provision and use of learning media, the lack of facilities in kindergartens maximize the use of themes to develop children's visual-spatial intelligence.

Implementing imaginative games of the treasure hunt to develop children's visual-spatial intelligence is carried out in two cycles with two actions each. There were still some deficiencies in the first cycle, including the children still did not understand the rules of play because they only just played this game. In the second cycle, based on the results of observations of children's activities during the learning process, it is seen that there is an increase in the development of visual-spatial intelligence. Children can follow instructions given during game activities. The children look active and respond to various questions asked by the teacher. The child does not hesitate in answering questions and can understand the rules of play, and can follow the instructions provided, and the child also feels happy when going through various kinds of obstacles.

The development of children's visual-spatial intelligence after the implementation of imaginative games to find treasure has increased. The second cycle results also showed that of the 20 indicators of the development of visual-spatial intelligence, the children showed that they were developing according to expectations on 4 indicators and developing very well on 16 indicators. Overall, the child has developed very well in coordinating eye-leg movements when passing obstacles and finding objects that match the treasure map's directions. This shows that imaginative play to find treasure can be used as a learning method to develop children's visual-spatial intelligence because it has a positive impact on learning activities carried out.

\section{REFERENCES}

[1] Armstrong, T. Setiap anak cerdas. Jakarta: Gramedia; 2003.

[2] Simatupang D, Ema L. Pengaruh kegiatan kolase terhadap kecerdasan visual-spasial anak usia 5-6 tahun di RA Masjid Agung Medan TA 2014/2015. Jurnal Bunga Rampai Usia Emas. 2017;1(1):7-13. Available from: https://jurnal.unimed.ac.id/2012/ index.php/jhp/article/viewFile/9277/8530.

[3] Wardhani D, Irawan EB, Sa'dijah C. Origami terhadap kecerdasan spasial matematika siswa. Jurnal Pendidikan: Teori, Penelitian, dan Pengembangan. 2016;1(5):905-9. Available from: http://journal.um.ac.id/index.php/jptpp/article/down load/6301/2691.

[4] Gunawan, MT. Pengaruh pembelajaran dengan permainan maze terhadap kecerdasan visual spasial anak usia dini. Bandung: UPI PRESS; 2015.

[5] Setyowati MN. Penerapan permainan kreatif mencari harta karun untuk meningkatkan 
kemampuan memecahkan masalah pada anak kelompok b di taman kanak-kanak. PINUS: Jurnal Penelitian Inovasi Pembelajaran. 2018 Feb 2;3(2):111-7. Available from: http://ojs.unpkediri. ac.id/index.php/pinus/article/download/11872/780.

[6] Muslihuddin. Kiat sukses melakukan penelitian tindakan kelas di sekolah. Bandung: Rizqi Press; 2010 .

[7] Muslich, M. Melaksanakan PTK itu mudah (classroom action research) pedoman praktis guru profesional. Jakarta: Bumi Aksara; 2011. 